\title{
Social Infrastructure Needs: Financing Through Digital Platform
}

\author{
Shruti Sharma, Adya Sharma
}

\begin{abstract}
Infrastructure funding needs are demanding like spouse where it's difficult to match demand with supply. This gap which is way too wide as India needs investment of ₹50 trillion ( US\$ 777.73 billion) in infrastructure by 2022to have sustainable development in the country; union budget 2018-19 allocated ₹4.56 lakh crore ( US\$ 63.20 billion) for the sector [1]; also, investment into the National Investment \& Infrastructure Fund (NIIF), Private equity and venture capital investments and various $M \& A$ deal in the infrastructure sector are also witnessed. Nevertheless, this is less than required and by the time funds are raised for new infrastructure, somewhere other existing infrastructure may be in need of upgrade; in essence, need of continuous and sustainable fund flow is need of the hour. However, when infrastructure funding is done,economic infrastructuregets default priority over social infrastructure. We find that plenty of funds which are available with individuals and companies are not utilized just because we don't have a convenient and efficient channel to route funds to specific projects. We analyse social infrastructure financing and limitations of financing capabilities, how alternative funding methods like crowdfunding can help in narrowing the funding gap. This paper talks about current financing practices and how a digital platform canact as aggregator and can capture community crowdfunding market which is still in nascent stage in India, transaction value in the Crowdfunding segment of India is meagre US\$1.7m in 2019 in comparison to China (US\$5,572m in 2019)[2]. Also, it can channelize India Inc's unspent Corporate Social Responsibility(CSR) amount which stood at almost 60k crore in duration of FY15-18; mostly due to inability to identify project to spend [3]. This platform can be promising and support in continuous and hassle-free flow of funds to the major/minor projects. Moreover, India is gearing up for smart cities and rapid urbanization and it's a sane thing to seek solutions before the issues arrive. This paper contributes by conceptualizing first of its kind 'aggregator model of crowdfunding' for social infrastructure.
\end{abstract}

Index Terms: Aggregator model, Crowdfunding, Digital platform, Donation, Social infrastructure.

\section{INTRODUCTION}

India requires to finish provisioned infrastructure, prepare for new infrastructure and to upgrade and maintain existing infrastructure as per population and economic growth.India's large cities have got suburban areas which occupy India's $1 \%$ land area but provide $18 \%$ of country's employment; it shows India's staggering pace of urbanization.

Citizens are more aware and expecting; at the same time fragility of social infrastructure and services lie bare in front of us in when they are exposed to floods andcyclone; and so

\footnotetext{
Revised Manuscript Received on September 10, 2019.

Shruti Sharma*, Faculty of Management, SCRI, Symbiosis International (Deemed University), Pune, Maharashtra, India.

(email: shruti0203@gmail.com).

Dr. Adya Sharma, SCMS, Symbiosis International (Deemed University), Pune, Maharashtra, India.

(email: adyaindia@gmail.com)
}

social infrastructure is critical for not only social but economic and political importance [4]. The high-powered expert committee (HPEC) estimates need of ₹39 lakh crores (at 2009-10 prices) for urban infrastructure in 20-year period from 2012 to 2032[5]. Traditionally government financed for social amenities, emergence of public-private model and municipal bonds is also witnessed; but these financing options are also not free from issues and lack sustainability when there is already a huge funding gap exits for infrastructure in total. This paper explores alternative financing tool and how this tool can route existing unused fund from companies' CSR kitty, bringing more form NRIs and unleash potential of donation from citizens and it leads us to crowdfunding on a digital platform. As government has strong role to play in social infrastructure financing and authorizing; active participation of government can provide it legitimacy to induce trust, increased citizen engagement for more responsive and accountable governance. Technology has the power to redefine nature and intensity of social engagement and there a strong need to interlink and integrate new tools and technologies in our democratic process to match steps with time and new generation for better efficiency, engagement methods.This paper focusses on donation-based crowdfunding (CF); equity $\mathrm{CF}$ regulations have not been framed and that is also out of our purview for social infrastructure financing as no financial returns are involved. As [6] suggests that case-based approach is especially suited to address How \& Why questions, we examined current Indian and international scenario of $\mathrm{CF}$, analysedvarious cases in point, reviewed literature for existing roles of government;and we propose an 'aggregator model of crowdfunding' for social infrastructure. Constituents of this framework, success and risk factors are also discussed. This model can unleash the 'power of the many' for numerous small projects which can cause a big change together.

\section{II.. CROWDFUNDING: WHY AND WHAT}

At municipal level, tax collection and utilization are bad, dependency on higher tier of government is an impediment and external sources are linked to financial soundness of municipality or Urban local Bodies (ULBs) and they are expected to generate funds in the future for servicing the debt and so not a very apt source of additional funding beyond a point. If we look at ULB's revenue, it stands at meagre $0.75 \%$ of the India's GDP; Whereas, this number stands at $4.5 \%$ for Poland, 5\% for Brazil and 6\% for South

Published By:

Blue Eyes Intelligence Engineering

\& Sciences Publication 
Africa [7] and it gives clarity on why spending by municipal bodies is lower than required for basic social amenities.Out of the 18 functions to be performed by municipal bodies, less than half have a corresponding financing source. After clarity in budget and expenditure allocations, it is also necessary to address matching functions to finances and ensuring accountability [8].

Unlike developed countries, applying user charges for free services or increasing them for some services always may not be best suited in Indian context; bond issuance has its own set of issues but municipal bonds are in vogue again; Recently, 94 cities got rated from AAA to D (lowest), to help them to raise money and only 55 cities got investment grade[9] and just because these cities are not financially sound to give returns on investment, citizen of these cities cannot be left behind.Union Housing and Urban Affairs Ministry's Atal Mission for Rejuvenation and Urban Transformation (AMRUT) has 11 reforms comprising 54 milestones to be achieved by the social body and credit rating of ULBs and floating municipal bonds is part of the reforms; credit rating is a prerequisite[10]. Pune municipal corporation (PMC) raised ₹200 crore in June,2017 through municipal bonds. Lack of planning and difference between political representatives led to a fiscal deficit of Rs 2.41 crore; annual interest rate for amount raised is $7.59 \%$ and due to cancellation of tenders and subsequent project delay, funds are kept in fixed deposits at 6.85\% [11]. PMC's plan is to raise ₹2,264 crore in five years for implementation of the $24 X 7$ water supply project under smart city initiative; however, first phase of raising turned out to be a dud with no outcome achieved.

Some authors point out value capture of land as supplementary financing mechanism; though it holds potential but as capital finance instrument but it cannot be a sustainable option as land sales cannot continue indefinitely[12].Another approach is public-private partnership (PPP); however mostly PPP targets to attract capital and curtail public sector involvement rather than to increase effectiveness and efficiency of service delivery [13]. Social sector financing option differs as the instruments are not particularly designed for intrinsic characteristics of social sector[14]; as the aim is not to maximize returns on investment for social projects. Literature mostly emphasize over the municipal bonds and user charges for financing needs.

Nuisances in current financing options impel us to explore alternative financing options for social infrastructure which leads towardscrowdfunding which is pooling of funds from group of investors through a digital platform for a specific project, business venture or social cause.If thefunds are raised towards social, artistic or other philanthropic purpose, mostly on a fin-tech platform through microfinancing, donations and social activities without in exchange for anything of financial value; it is recognised as donation-based $\mathrm{CF}[15],[16]$; however, concept of volunteering is also evolving with time and in Indian context Seva (unpaid selfless service like in Gurudwara) is a perfect example of it where anyone can go and contribute.The concept of mobilizing funding in small pieces is old and can be found in every incorporation [17]; CF is not a novel idea itself as for long time donations to temples, schools, food charity to election CF have existed in India.Crowdfunding can be grouped as 'crowdfunding' (donation and reward models) and 'crowdfunding investing' (equity, debt and royalty models) [18]. [19] analysed factors of appropriate technology which brings social innovation and results in developing local and cultural environment, and found that CF can finance sustainable projects.

This paper focuses on crowdfunding as a combination of donations and non-monetary reward-based $\mathrm{CF}$ as they are free from regulatory hurdles [20] and further we seek to answer the question that how this mode of CF can help in funding social infrastructure. Reason of including nonmonetary reward-based $\mathrm{CF}$ is that sometimes donors expect a tangible but non-financial reward like a certificate of appreciation, social recognition or acknowledgment like in case of Rotterdam pedestrian bridge; which is first public infrastructure project to be crowdfunded in 2011 and name of each donor is inscribed on a wooden plank who donated more than $€ 25$ [21]. It provided symbolic collective ownership and recognition to donors which works as a strong motivation to donate.

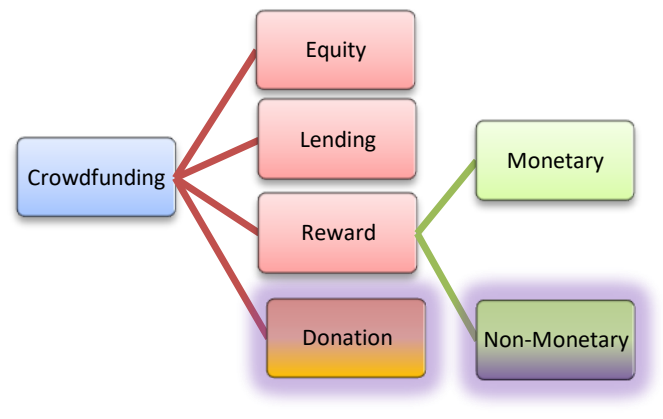

Fig. 1. Types of CF

Notably, donation-based CF doesn't need external motivation and donors donate out of intrinsic motivation and altruism; however, benefits and rewards interactively impact crowdfunding success[22]. People are more likely to contribute to projects that will directly impact them or that are well aligned with their interests and in this manner they act little selfish; this also results in money being withdrawn from a different 'personal pot' of money which was untapped for the financing of projects for social good [23].

Crowdfunded social infrastructure is mostly place-based and donors generally belong from there, often local residents and people who moved out but emotionally still connects, donate due to home bias; though online $\mathrm{CF}$ has removed distance-related frictions [24] and some causes extend beyond locality or city/state like tackling natural disasters and donors from everywhere come forward to help[25]. Another important factor is participation in movement and feeling of making a difference. Donors tend to give recurring donations if they are regularly informed about project progress; they get an opportunity to solve local issues with priority and efficiency, to help, seek satisfaction and appreciation and are benefitted with better amenities and improved quality of life.Other potential donors include 
companies which can endorse fundraising campaigns in their CSR initiatives, and utilize it for brand visibility, awareness creation, community involvement, and social recognition which not only improve sales performance but aids in fundraising for CSR [16] and NRIs who have money and intention to help both but channels to route that money to specific projects conveniently is not explored.

\section{CROWDFUNDING PLATFORMS\& CURRENT PRACTICES}

Most of the CF platforms are generic but specific social CF platform are also prominent now and they usually adopt two models of funding; (1) all or nothing (AON) and (2) keep-it-all (KWYR) [26]. AON requires a project or cause to reach $100 \%$ of its financing targets in defined time period, else funds are returned to the donors considering that funds are insufficient to finish projectwhereas KWYR is suitable for projects which are not deadline bound or specific budget oriented and raised amount still can support the cause. Various International and Indian platforms are in this domain with different models and modus operandi.

\section{A. International CF Platforms}

1. Spacehive is world's first social CF platform which funded 58 social projects with $£ 1.8$ million in 2012-14. It combines community crowdfunding with institutional match funding and uses AON model; sub-national governments (SNGs), businesses can match-fund community projects that are aligned with their strategic objectives or areas of interest.

2. CitizenInvestor allows only government entities, usually municipal governments or their official partners to submit the project. Citizens can propose independent project through petition process and if it is approved by appropriate government authority, it becomes an official project. They focus more on small donations, uses AON model and all donations are tax exempted [23].

3. Ioby enables citizens to collect and organize all kinds of capital, such as cash, social networks, in-kind donations, volunteer time and advocacy. Projectwise AON or KWYR model is decided though AON is more common.

These platforms screen projects and some constraints are also used as filter according to project; for example, project initiator needs to be local for Ioby or CitizenInvestor only pursues project by or supported by SNGs whereas co-city of

\section{B. Indian CF Platforms}

1. Ketto is donation-based platform and focuses on community projects, creative arts and personal development, clearly defining objectives, needs, goals, timescales, money needed and what they are sponsoring; they are open for CSR funds too and uses KWYR model.

2. Fuel A Dreamis a non-monetary reward based crowdfunding platform with focus on creative arts projects, social causes and charities and gives option of choosing either AON or KWYR model. They focus on quality rather than quantity and restrict themselves to 20 projects per month.

3. Milaap is hybrid of loan and donation platform as it started as micro loan platform; added donation option in Paris only allows govt to participate not to initiate [25].

2014 and now has donors and lenders from over 120 countries for approximately to 50 thousand projects and amount raised is over $\$ 12.7$ million[27].

Crowdfunding (CF) platforms for social purposes combine the latest developments of the digital economy with technologies and finance that could be an innovative response to problems and needs of the society. Governments are engaging and partnering with social communities for community projects and utilizing alternative finance through digital CF platforms.Different countries have seen different types of CF intermediaries emerging [24] (Lee et al.,2016) and its paramount to seek utilization of this tool to fullest for enhanced public amenities and benefits and so this paper explores how digital or phygital (physical plus Digital) $\mathrm{CF}$ model can help bridging India's ever widening social infrastructure funding needs. India is a developing nation and unsurprisingly, healthcare is the most funded and social causes are second in category unlike USA where one can raise funds from crazy innovation ideas to community projects; the causes which India caters to are about basic amenities and differs from western counterparts.

\section{HOW READY INDIA IS?}

India had 44.3 crore internet users and set to reach to 66.64 crore in 2023. India already is the second-largest online market worldwide and still with large untapped potential. India's major chunk of internet users are mobile phone internet users and it is set to reach at 49.2 crore by 2022[28]. Another booster for CF comes from social media networks and even more with the penetration of smartphones [29] which play an important role in information dissemination and democratisation of social crowdfunding ecosystem. India has large number of social media users (Facebook-27 crore users andWhatsApp- 20 crore monthly active users in India[30]); it is imperative to embed sharing by social networks in platform design. Every good cause towards society can be achieved through CF and citizen have achieved many successful projects worldwide through this process without government support. Biggest not for profit campaign success case is Wikipedia, which is a non-profit organization with huge cash reserve $(\$ 3 \mathrm{bn}$ approximately) and it built the largest collection of free knowledge in recorded history by crowdfunding; however, people have raised alarm over wiki foundations rising expenses and reserves when it tried to raise more funds [31]. Wikipedia also invites volunteers to edit and improve articles, write and debug codes and so on. In case of social works, government permission is required; involving government becomes sensible.

Citizens are interested in making their lives and surroundings better and can do so if they get funds and required support. Apart from other motivations for donor, well managed platform and user interface, clear descriptions and matching of finances to functions, trust is a critical element for donors to support the cause. Elimination of trust issues can be dealt with dedicated CFC platform with 
endorsement/collaboration with subnational or national govt. Government can leverage 'power of the many' individuals and manage the interlink between various parties [32].Transparency and accountability support the notion of trust and citizen engagement through social crowdfunding projects help to ensure these traits.Screening of projects based on their deliverability and accountability is needed and SNG needs to ensure quality and timescale standards [23].

\section{ROLE OF GOVERNMENT}

We analyse some existing cases;

1. Punjab government framed guidelines for school financing to involve corporates, NRIs, NGOs to participate for infrastructure improvement in state run schools; an institutional committee comprising of member of school management and funders; a dedicated cell to be set up in the office of school education Director General. Department of school education will post infrastructure, books, sports, approved e-content related or any other requirements on website and funders can choose to donate in one or many schools; no commercial activity will be allowed [33].

2. 'Bharat Ke Veer' is a fundraiser by Ministry of home affairsfor Indian paramilitary forces where donations can be made to individual accountor to the total corpus. It is managed by a trust and donations are tax exempted under 80(G) of Income Tax Act [34]. American India Foundation (AIF) contributed $\$ 1 \mathrm{mn}$ (approximately ₹7 crores) to Bharat ke Veer corpus; it also donates for other causes [35].

3. Maharashtra state government organised 'Transform Maharashtra' project for young college students from the state to provide solutions programmes for challenges faced by the state. A team of Mumbai and Pune based college students won this thematic competition for their project idea- 'One village, one library'; they plan to crowdfund for it and to expand the programme, will take help of CSR funds, if needed[36]. Another similar initiative is one library per village which is an initiative in Kerala; people can donate cash and books online and offline both; certain points are given for books collection or as address for ordering [37].

4. Government of Gujarat introduced first social crowdfunding platform called 'Fund for Unity' which is an interactive digital platform under 'Statue of Unity' project; contributors can access projects and donate through secure payment gateway and contributions are tax exempted under section $80(\mathrm{G})$ of Income Tax Act of India; it allows everyone to contribute [38].

[39] suggests four roles for government/SNGs; Promoter, Curator, Facilitator and Platform. Promoter- In this pathway, organization acts as the main fundraiser, taking responsibility for receiving and spending the money, using an existing platform. PM relief fund (no choice of project). Curator- Endorsing the idea on other CF platform which are aligned with what govt is doing already or planning to do with some degree of due diligence as they would own part responsibility project fails to deliver.Facilitator- The organization supports its members, subsidiaries or partners who want to use crowdfunding to fund their projects by providing training and expertise. Platform- An organization creates its own crowdfunding platform and hosts campaigns entirely on its own site. If government doesn't want to develop own platform, white labelling can be opted; third party can make $n$ manage platform and government only provides its name with regulatory conditions for better management.

It also equally makes sense to use expertise of best existing platforms which can advise, manage the campaign and can also garner support of social media [39]. Examples also point out the potential of harvesting CSR funding and their potential to positively impact design, development and money raised. [23] classify roles as Passive observer, Active supporter, Activity generator and Confident leader. [40]forwards donation-based patronage model where donor receives no rewards for his funding, but only altruism, generosity or personal and corporate promotion.

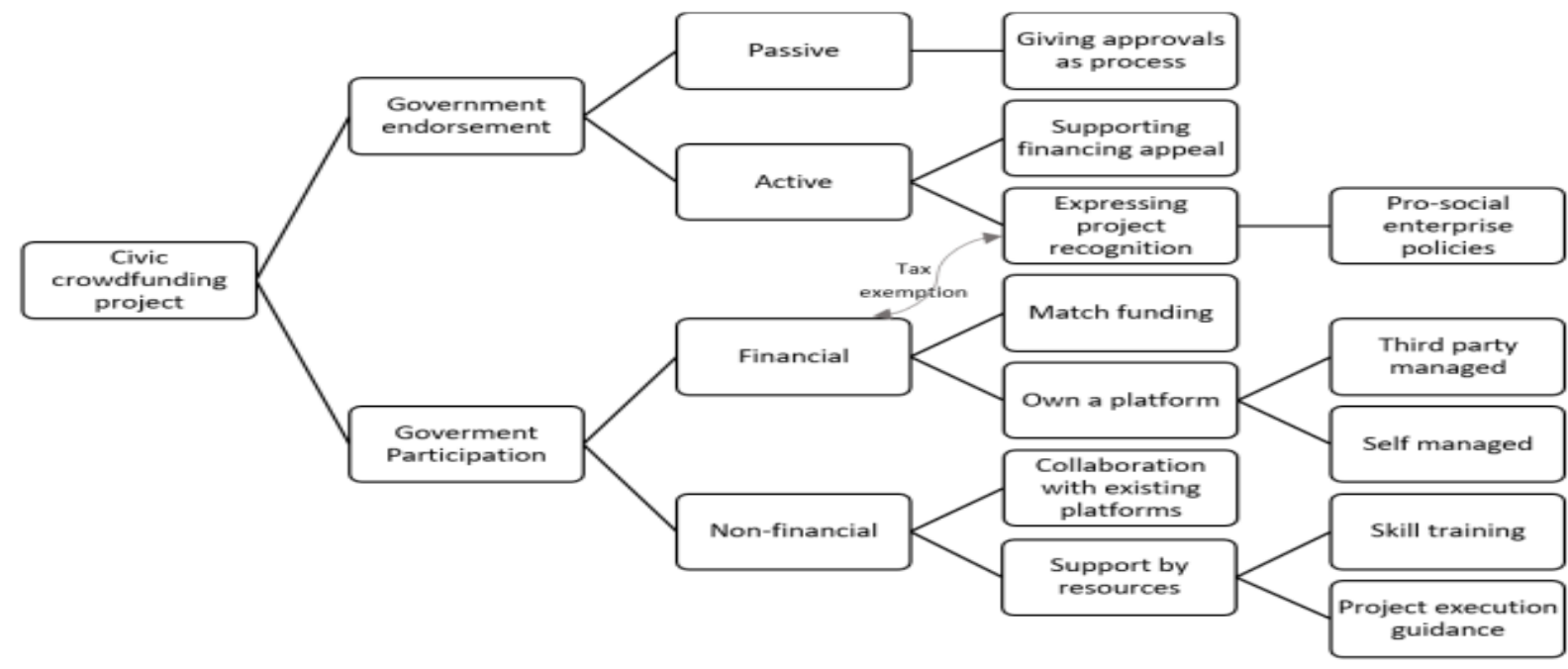

Fig 2: Roles of government 
Fig. 2 shows existing practices in world and India; some roles may not require government to invest, some may require match funding and some full financial backing. Looking these roles through lens of existing cases, it can be established that some models are more successful in Indian context. Some donors may or may not opt for tax exemption and so it may act as active legitimising endorsement as well as financial incentive participation.

\section{AGGREGATOR MODEL FOR SOCIALCROWDFUNDING}

Crowdfunding is in its infancy in India; we propose a web and mobile based aggregator model framework for social crowdfunding towards government proposed/authorized projectsfor which government can opt for digital presence; preferably third party managed as we have seen cases of government managed self-proposing project model failing. For social crowdfunding, aggregator can be understood as the organization which owns and manages a web or mobilebased software application, and by means of the application it enables a potential donor to connect with social infrastructure or amenities project creator under the brand name or trade name of the aggregator[41]; it should bridge the gap between donors and requirement area. It should clearly stipulate need for project, goals, projects phases, budget and cost heads, head/creator of projects, required amount and benefits sought.It can link with and give search option of physical establishments like government orphanages, old age home or schools which don't have online presence in system and open it for donations and visits by patrons; on the lines of food delivery and hotel aggregators like Zomato, Swiggy and Oyo.It can link with existing platforms and selected government endorsed projects should be displayed; on the lines of Trivago which only aggregates information from existing online hotel booking platforms. Any donor can donate using the app and it can capture huge potential in donation crowdfunding. A convenient aggregator app with user friendly features, ease of access, convenience and safe and various payment methods is desirable. Project creators can be given points on their proven track record similar to rating, project progress information can be shared through notifications; comments and feedback section should also be enabled. Loyalty points can be issued to donors and after certain number of points a token of respect or acknowledgement can be issued or for specific infrastructure donation, name can be put as we have seen in case of Rotterdam bridge or in temples. Online recognition for a small donation and/or gets a personalized gift or publicized recognition for large donations can be desirable [16].

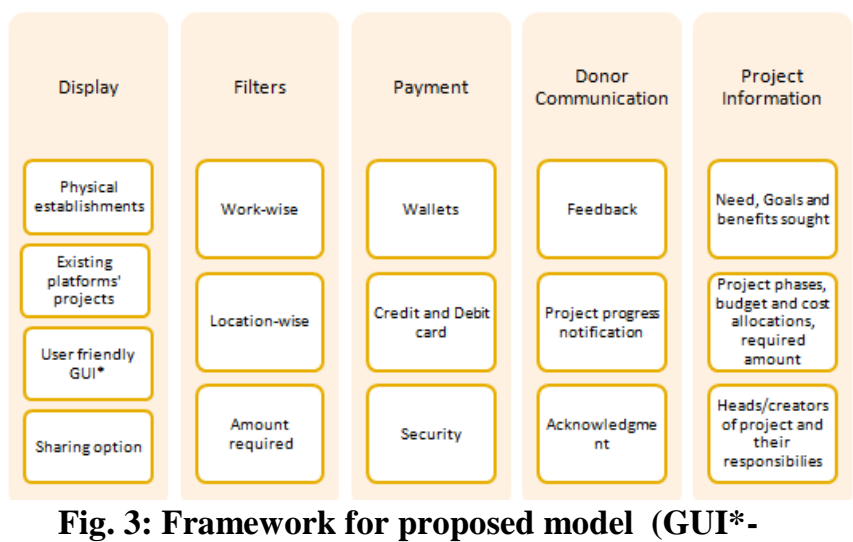

Graphical User Interface)

\section{DISCUSSION}

In this paper we examined current social amenities' state, available financing options and why they are insufficient and unsustainable; review of literature and analysis of cases lead us to sustainable model of social infrastructure financing which is donation crowdfunding with the help of digital platform which also integrates physical establishments and evolves as a phygital model.

There are various ingredients in its success; strong signal of legitimacy is an important ingredient of success for $\mathrm{CF}$ campaign [42],[43], tax relief given by government itself increases legitimacy and trust factor. It's important to clearly define goals, budget, expenditure, benefits and people involved and their responsibilities with an open option of donor's visit if they want to. Social crowdfunding can enhance citizen participation opportunities; government and citizens both can work on bottom up or pull approach rather than top down push approach for small scale projects and can take middle path in some projects by using match funding and institutional guidance. Generally, CF as an alternative finance method lures authority for being a financing option but as involvement progresses, social benefits outweigh any financial gains [23].

Misuse of funds and resources is minimized as full information disclosure prevents deviation from pre-decided cost and budget allocation and feedback mechanism works as monitoring; utilization of the collective intelligence of the crowd also becomes possible; commenting on ideas of others create rich interaction environment propagates innovative thinking that is useful for society [44] and projects for generating new and refined ideas. Funding gap for social amenities is a bitter reality but citizens are rightful to have basic/better amenities and $\mathrm{CF}$ should be seen as 'widening the funnel' or supplementary financing only.

Crowdfunding is dealing with many onetime projects and long term operational and maintenance issues are not dealt with [25]; however, in case of Wikipedia and Bharat ke Veer, these issues are tackled. Also, funders may lose interest after initial euphoria and thus its suitable more for one-time small-scale projects; with CSR funds or government match making only the scale can be larger. Post the completion, local authorities or municipality will be 
responsible for operations and maintenance in most cases; which may be a possible drawback if citizenengagement is not continued. Leaders, managers, authorities and their managerial capabilities can make huge difference in execution and outcome of projects; same initiatives may area with different team. Indian CF market has been limped by dubious campaigns and as a result many people think twice before supporting a child with critical disease. Fear, lack of trust and asymmetric information may limit its scope and application; ensuring transparency, accountability and regular information update will be the key elements to soothe these issues down[45].

Funding risk and information asymmetry also impacts citizens in different ways Social infrastructure can have skewed unevenly distribution as funding concentration is less in rural areas [46]; however, [47] found that local characteristics of projects do not affect ability to raise funds which clearly soothes this concern down. By 2021, 83 crore internet users are projected in India [48]; rural areas are connectedprimarily through smartphones rather than laptops; so online literacy is an important factor. Use of digital platform improves citizen participation, public discourse and social engagement but it should not be limited to only online dimension but physical models should be integrated; it raises the awareness levels and contribution levels both [49]; also, physical establishments which are not available for online donations should be brought in the ambit. Increasing the reach stands both for offline physical establishments as well as donors who are not online or with low online literacy; thus, use of Phygitalmodel can be the optimum approach.

Repeated CF is viewed as government's inability to finance social infrastructure [50], though it should be seen as synergy building and positive dialogue between government and their citizens enhancing the democratic thread of country. It should be treated as a complement rather than a substitute for traditional financing methods [51].Enhanced citizen engagement helps government to be transparent, responsive and accountable. Citizens the social goods or infrastructure more when they are engaged in the process of creating it through participation [24] as the sense of collective ownership crawls in and so the resultant benefits are much more than financing; also the public private engagement makes selection of projects efficient too; however, citizens generally are not specialists or experts in social projects and that may have their own subjective criteria about project selection.

Crowdfunding research is in initial phase and phenomena of social crowdfunding as an option is not being explored. Proposed aggregator model bridges the gap between donors and social project creators and holds the potential to unlock sustainable funds which are yet untapped. Aggregator model provides information consolidation which is user friendly and enhances convenience; putting it into action, can unleash the power of the many small.

This paper does not talk about the quantum of potential donation which needs to be studied. Other linkages like; exploring option of enhanced utilization of payment mechanisms and e-commerce websites/apps can be explored; for example, PayTM digital wallet also provided result in different outcomes in different areas or in same

link to donate towards CRPF funds and it led us to explore viability of exploring idea of link to donate cash or linked products which further can enhance these businesses too while fulfilling a cause towards society; study of how to achieve it, is also desirable.

\section{REFERENCES}

1 Information

onhttps://www.ibef.org/industry/infrastructure-sectorindia.aspx

2 Information

onhttps://www.statista.com/outlook/335/119/crowdfundi ng/india

3 Information

https://www.thehindubusinessline.com/economy/indiainc-spent-50000-cr-on-csr-in-fy15-18-but-unspentamount-higher/article26399672.ece

4 Mohanty, P. K., Misra, B. M., Goyal, R., \&Jeromi, P. D. (2007). Municipal finance in India: An assessment. Development Research Group Study, (26).

5 Information

https://economictimes.indiatimes.com/news/economy/inf rastructure/rs-39-lakh-crore-needed-for-infra-in-urbanareas-until-2032-hardeep-singh-

puri/articleshow/62340323.cms?from=mdr

6 Yin, R. K. (2003). Case study research: Design and methods. (Sage Publications, Thousand Oaks). CA2003.

7 Information

on http://www.careratings.com/upload/NewsFiles/Studies/St udy\%20on\%20ULBs\%20Nov\%202010.pdf

8 Bird, R. M. (2000). Intergovernmental fiscal relations: Universal principles, local applications (No. paper0002). International Center for Public Policy, Andrew Young School of Policy Studies, Georgia State University.

9 Information on https://www.livemint.com/Politics/KjJbJIc7eENNMAqT onjqcN/94-cities-get-Crisil-ratings-as-urban-localbodies-prepare-f.html

10 Information on https://en.wikipedia.org/wiki/Atal_Mission_for_Rejuven ation_and_Urban_Transformation

11 Information on https://www.hindustantimes.com/punenews/200-crore-raised-through-through-municipalbonds-stuck-in-pmc-s-to-do-list/storyxlFLWgGuhVurTZAikQ2YEI.html

12 Information on http://financingcities.ifmr.co.in/blog/category/municipalfinance/

13 Bagchi, Soumen (2001): "Financing Capital Investments in Urban Infrastructure - Constraints in Accessing Capital Market by Urban Local Bodies", Economic and Political Weekly, January 27.

14 Guézennec, C. and Malochet, G., "Impact investing: a way to finance the social and solidarity economy: an international comparison", Commissariat General à la Stratégie et à la Prospective,02, Paris, 2013

15 Information https://www.sebi.gov.in/sebi_data/attachdocs/140300561 5257.pdf

16 Rijanto, A. (2018). Donation-based CF as corporate social responsibility activities and financing. Journal of General Management, 43(2), 79-88.

17 Fiedler, S., \&Horsch, A. (2014) Crowdinvestingalsfinanzierungsalternative. ZfKEZeitschriftfür KMU und Entrepreneurship, 62(1), 91-98. 
18 Best, J., Neiss, S., Swart, R., \& Lambkin, A. (2013). Scaling innovation: Crowdfunding's potential for the developing world. Information for Development Program (infoDev), The World Bank.

19 Moon, Y.; Hwang, J. Crowdfunding as an Alternative Means for Funding Sustainable Appropriate Technology: Acceptance Determinants of Backers. Sustainability $2018,10,1456$

20 Information on http://economictimes.indiatimes.com/articleshow/668919 83.cms?from $=$ mdr\&utm_source $=$ contentofinterest\&utm_ medium=text\&utm_campaign $=$ cppst

21 Information http://www.morethangreen.es/en/luchtsingel-pedestrianbridge-crowdfunding-urbanism-in-rotterdam/

22 Zhang, H., \& Chen, W. (2019). Crowdfunding technological innovations: Interaction between consumer benefits and rewards. Technovation, 84, 11-20.

23 Griffiths, H., Madden, P., \& Howe, C. (2016). Social Crowdfunding-A guidebook for local authorities. Retrieved September, 6, 2017.

24 Lee, C. H., Zhao, J. L., \&Hassna, G. (2016) Government-incentivized CF for one-belt, one-road enterprises: Design and research issues. Financial Innovation, 2(1), 2.

25 Charbit, C., \& Desmoulins, G. (2017). Social Crowdfunding: A collective option for local public goods? OECD Regional Development Working Papers, 2017(2), 1.

26 Zhang, B., \& Deer, L. (2016). Harnessing Potential: The Asia Pacific Alternative Finance Benchmarking Report, 2016.

27 Chandiramani, J., \& Patil, G. (2018). Crowdfunding: Can It Support Urban Local Bodies in India? In Crowdfunding and Sustainable Urban Development in Emerging Economies (pp. 232-254). IGI Global.

28 Information onhttps://www.emarketeducation.in/powerinternet-penetration-online-india/

29 Martínez-Climent, C., Costa-Climent, R., \&Oghazi, P. (2019). Sustainable Financing through Crowdfunding. Sustainability, 11(3), 934.

30 Information hatsapp-now-has-1-5-billion-monthly-active-users-200million-users-in-india/1044468/

31 Information https://www.theregister.co.uk/2012/12/20/cash_rich_wiki pedia_chugging/

32 Lehner, O. M., \& Nicholls, A. (2014). Social finance and crowdfunding for social enterprises: A public-private case study providing legitimacy and leverage. Venture Capital, 16(3), 271-286.

33 Information on https://www.businessstandard.com/article/pti-stories/punjab-govt-to-take-helpof-corporates-ngos-for-improving-school-infra118083001055_1.html

34 Information https://en.wikipedia.org/wiki/Bharat_Ke_Veer)

35 Information on https://aif.org/indian-diaspora-in-the-usraises-an-unprecendented-one-million-dollars-for-bharatke-veer/

36 Information on https://www.dnaindia.com/india/reportcollege-students-to-crowdfund-library-project-in-ruralmaharashtra-2424422

37 Information on https://www.olpv.org/

38 Information on https://www.prnewswire.com/newsreleases/government-of-gujarat-introduces-indias-firstcivic-crowdfunding-platform-539117621.html

39 Davies, R., (2014), Social Crowdfunding: Participatory Communities, Entrepreneurs and the Political Economy of Place. MIT Center for Social Media.
40 Mollick, E. 2014. "The Dynamics of Crowdfunding: An Exploratory Study." Journal of Business Venturing 29: 1-16.

41 Panigrahi, Ashok and Shahi, Shambhavi and Rathore, Amarsingh, Success Story of a Start-Up - A Case Study of OLA Cabs (January 25, 2018). IOSR Journal of Business and Management, Volume 20, Issue 2. Ver. II (February. 2018), PP 30-37. Available at SSRN: https://ssrn.com/abstract=3122936

42 Lehner, O. M. 2013. "Crowdfunding Social Ventures: A Model and Research Agenda." Venture Capital 15 (4): 289-311

43 Stemler, A. R. (2013). The JOBS Act and crowdfunding: Harnessing the power-and money-of the masses. Business Horizons, 56(3), 271-275.

44 Belleflamme, P., T. Lambert, and A. Schwienbacher 2014. "Crowdfunding: Tapping the Right Crowd." Journal of Business Venturing 29 (5): 585-609

45 Turi, A. N., Domingo-Ferrer, J., Sánchez, D., \& Osmani, D. (2017). A co-utility approach to the mesh economy: the crowd-based business model. Review of Managerial Science, 11(2), 411-442.

46 Davies, R., (2015), Three provocations for social crowdfunding. Information, Communication and Society, Vol. 18, Iss. 3, 2015

47 Brent, D. A., \&Lorah, K. (2019). The economic geography of civic crowdfunding. Cities, 90, 122-130.

48 Information on https://inshorts.com/en/news/internetusers-in-india-to-double-to-83-cr-by-2021-report1497117831074

49 Bernardino, S., \& Santos, J. F. (2017, February). Potential of social crowdfunding to the intelligence of cities and social innovation: an exploratory study. In Atas da Conferência da Associação Portuguesa de Sistemas de Informação (Vol. 16, No. 16, pp. 311-323).

50 Brabham, D. (2013), Crowdsourcing, Cambridge, MA: MIT Press

51 Kraus, S.; Burtscher, J.; Vallaster, C.; Angerer, M. Sustainable Entrepreneurship Orientation: A Reflection on Status-Quo Research on Factors Facilitating Responsible Managerial Practices. Sustainability 2018 , 10, 444. [CrossRef] 